\title{
PENGARUH KEPEMILIKAN MANAJERIAL, STRUKTUR AKTIVA, UKURAN PERUSAHAAN, PERTUMBUHAN PENJUALAN DAN PROFITABILITAS TERHADAP KEBIJAKAN UTANG PADA PERUSAHAAN SEKTOR ANEKA INDUSTRI YANG TERDAFTAR DI BURSA EFEK INDONESIA (BEI) PERIODE 2012 - 2016
}

\author{
Umi Mardiyati \\ Fakultas Ekonomi Universitas Negeri Jakarta \\ E-mail: umi.mardiyati@gmail.com \\ Qothrunnada \\ Fakultas Ekonomi Universitas Negeri Jakarta \\ E-mail: qothrunnadah@gmail.com \\ Destria Kurnianti \\ Fakultas Ekonomi Universitas Negeri Jakarta \\ E-mail: destria.kurnianti@gmail.com
}

\begin{abstract}
ABSTRAK
Penelitian ini bertujuan untuk mengetahui pengaruh kepemilikan manajerial, struktur aktiva, ukuran perusahaan, pertumbuhan penjualan dan profitabilitas terhadap kebijakan utang pada perusahaan aneka industri yang terdaftar di BEI periode 2012-2016 dengan 96 unit sampel. Model yang digunakan dalam penelitian ini adalah data panel dengan pendekatan Fixed Effect Model dan Random Effect Model. Hasil penelitian menunjukkan bahwa kepemilikan manajerial dan struktur aktiva tidak berpengaruh terhadap kebijakan utang (DER dan DAR), ukuran perusahaan positif dan signifikan terhadap DER dan negatif dan signifikan terhadap DAR, sedangkan pertumbuhan penjualan dan profitabilitas positif dan signifikan terhadap DER tetapi tidak berpengaruh terhadap DAR. Hasil robustness check menunjukkan kepemilikan manajerial, struktur aktiva dan ukuran perusahaan memiliki hasil robust. Sedangkan pertumbuhan penjualan dan profitabilitas memiliki hasil tidak robust.
\end{abstract}

Kata kunci: Kebijakan Utang, Kepemilikan Manajerial, Struktur Aktiva, Ukuran Perusahaan, Pertumbuhan Penjualan, Profitabilitas 


\section{PENDAHULUAN}

Tujuan perusahaan adalah meningkatkan kemakmuran para pemilik saham. Untuk itu dalam memenuhi kebutuhan pendanaan perusahaan, pendanaan eksternal berupa utang lebih diminati oleh pemilik saham. Namun, sebagian manajer tidak menginginkan pendanaan eksternal karena utang memiliki risiko yang tinggi bagi perusahaan. Oleh sebab itu kebijakan utang sering digunakan dalam pengambilan keputusan pendanaan sebagai bentuk monitoring terhadap tindakan manajer yang dilakukan dalam pengelolaan perusahaan (Indahningrum dan Handayani, 2009).

Kebijakan utang diproksikan dengan debt to equity ratio (DER) dan debt to asset ratio (DAR). Hal ini dikarenakan DER dapat mencerminkan besarnya proporsi antara total debt dan total modal sendiri. Sedangkan DAR mencerminkan seberapa besar total aset perusahaan dibiayai dengan total debt (Susanti, 2013). Kepemilikan manajerial menjadi salah satu faktor yang mempengaruhi kebijakan utang suatu perusahaan. Hasil penelitian Soesetio (2008) dan Nafisa (2016) menyatakan bahwa kepemilikan manajerial berpengaruh negatif signifikan terhadap kebijakan utang. Namun hasil penelitian tersebut bertentangan dengan hasil penelitian Indahningrum dan Handayani (2009) dan Junaidi (2013) yang menyatakan bahwa kepemilikan manajerial tidak berpengaruh signifikan terhadap kebijakan utang.

Struktur aktiva adalah perbandingan antara aktiva tetap dengan total aktiva (Brigham dan Houston 2013: 97). Hasil penelitian Ernayani (2015) dan Ratnaningsih (2016) menyatakan struktur aktiva berpengaruh terhadap kebijakan utang. Namun hasil penelitian tersebut bertentangan dengan hasil penelitian Puspitasari dan Manik (2016) dan Hani dan Rahmi (2014) yang menyatakan bahwa struktur aktiva tidak berpengaruh terhadap kebijakan utang.

Ukuran perusahaan digunakan untuk mengetahui besarnya jumlah alokasi untuk tiap komponen aset. Hasil penelitian Mahnazmahdavi et. al (2013) dan Nafisa (2016) menyatakan bahwa ukuran perusahaan memiliki pengaruh positif terhadap kebijakan utang. Namun hasil penelitian tersebut bertentangan dengan hasil penelitian Narita (2012) dan Hidayat (2013) yang menyatakan bahwa ukuran perusahaan tidak berpengaruh terhadap kebijakan utang. 
Pertumbuhan penjualan merupakan keberhasilan investasi pada periode sebelumnya yang dapat memprediksikan investasi di periode berikutnya dengan melihat peluang pasar. Hasil penelitian Hidayat (2013) dan Mahnazmahdavi et. al (2013) menyatakan bahwa pertumbuhan penjualan berpengaruh positif signifikan terhadap kebijakan utang. Namun hasil penelitian tersebut bertentangan dengan hasil penelitian Damayanti dan Hartini (2013) dan Resino et. al (2015) yang menyatakan bahwa pertumbuhan penjualan tidak berpengaruh terhadap kebijakan utang.

Profitabilitas diproksikan dengan return on asset (ROA). Hasil penelitian Mardiyati et. al (2014) dan Hayat et. al (2016) menyatakan bahwa profitabilitas berpengaruh negatif signifikan dengan utang. Namun hasil penelitian tersebut bertentangan dengan hasil penelitian Ratnaningsih (2016) menyatakan bahwa profitabilitas tidak berpengaruh terhadap kebijakan utang.

Berdasarkan uraian dan permasalahan pada latar belakang di atas maka penulis tertarik untuk melakukan penelitian dengan judul "Pengaruh Kepemilikan Manajerial, Struktur Aktiva, Ukuran Perusahaan, Pertumbuhan Penjualan dan Profitabilitas Terhadap Kebijakan Utang pada Perusahaan Sektor Aneka Industri yang Terdaftar di Bursa Efek Indonesia (BEI) Periode 2012 - 2016”.

\section{RUMUSAN MASALAH}

Berdasarkan penjelasan di atas, maka dapat diidentifikasikan masalah-masalah dalam penelitian ini adalah sebagai berikut:

1. Apakah kepemilikan manajerial berpengaruh terhadap kebijakan utang pada perusahaan sektor aneka industri yang terdaftar di BEI periode 2012-2016?

2. Apakah struktur aktiva berpengaruh terhadap kebijakan utang pada perusahaan sektor aneka industri yang terdaftar di BEI periode 2012-2016?

3. Apakah ukuran perusahaan berpengaruh terhadap kebijakan utang pada perusahaan sektor aneka industri yang terdaftar di BEI periode 2012-2016?

4. Apakah pertumbuhan penjualan berpengaruh terhadap kebijakan utang pada perusahaan sektor aneka industri yang terdaftar di BEI periode 2012-2016?

5. Apakah profitabilitas berpengaruh terhadap kebijakan utang pada perusahaan sektor aneka industri yang terdaftar di BEI periode 2012-2016? 


\section{TUJUAN PENELITIAN}

Berdasarkan rumusan masalah di atas, maka tujuan penelitian ini adalah untuk menguji secara empiris pengaruh:

1. kepemilikan manajerial terhadap kebijakan utang pada perusahaan sektor aneka industri yang terdaftar di BEI periode 2012-2016 .

2. struktur aktiva terhadap kebijakan utang pada perusahaan sektor aneka industri yang terdaftar di BEI periode 2012-2016.

3. ukuran perusahaan terhadap kebijakan utang pada perusahaan sektor aneka industri yang terdaftar di BEI periode 2012-2016 .

4. pertumbuhan penjualan terhadap kebijakan utang pada perusahaan sektor aneka industri yang terdaftar di BEI periode 2012-2016.

5. profitabilitas (ROA) terhadap kebijakan utang pada perusahaan sektor aneka industri yang terdaftar di BEI periode 2012-2016.

\section{KAJIAN TEORI}

\section{Teori Pecking Order}

Pecking order theory merupakan suatu model struktur pendanaan yang mengikuti suatu hierarki yang bersumber dari laba ditahan, utang dan terakhir ekuitas untuk mengisi komposisi struktur modal perusahaan (Ernayani, 2015). Menurut Hidayat (2013) pecking order theory menjelaskan mengapa perusahaan yang profitable pada umumnya meminjam dalam jumlah yang sedikit. Hal tersebut dikarenakan sumber dana internal perusahaan cukup untuk memenuhi kebutuhan investasi yang diperoleh dari keuntungan yang didapat perusahaan. Sedangkan pada perusahaan yang kurang profitable cenderung memiliki utang yang lebih besar karena sumber dana internal mereka tidak cukup dan lebih menyukai utang sebagai sumber dana eksternal.

\section{Kebijakan Utang}

Kebijakan utang adalah keputusan manajemen perusahaan mengenai besar kecilnya pendanaan melalui utang sebagai sumber pembiayaan operasional suatu perusahaan (Puspitasari dan Manik, 2016). Besarnya modal suatu perusahaan menjadi pertimbangan tiap perusahaan untuk membiayai operasional perusahaannya dengan menggunakan pendanaan internal atau pendanaan eksternal (Ratnaningsih, 2016). Tujuan lain diperlukannya suatu kebijakan utang adalah agar perusahaan dapat mengelola dana 
perusasahaan secara efektif. Kebijakan utang dapat diukur dengan menggunakan rasio keuangan debt to equity ratio (DER) dengan rumus sebagai berikut:

$$
\mathrm{DER}=\frac{\text { Total Debt }}{\text { Total Equity }} \text { dan DAR }=\frac{\text { Total Debt }}{\text { Total Asset }}
$$

\section{Kepemilikan Manajerial}

Kepemilikan manajerial merupakan besarnya jumlah kepemilikan saham oleh pihak manajemen dari seluruh modal saham perusahaan saat ini (Indahnigrum dan Handayani, 2009). Adanya kepemilikan saham oleh pihak manajemen menjadi suatu bentuk monitoring terhadap kebijakan-kebijakan yang digunakan oleh manajemen perusahaan. Semakin besar kepemilikan manajerial pada perusahaan, maka pihak manajemen akan lebih berusaha semaksimal mungkin untuk memenuhi kepentingan pemegang saham dengan mengurangi risiko keuangan melalui penurunan tingkat utang (Fama, 1980). Kepemilikan manajerial dapat diukur dengan menggunakan rumus sebagai berikut:

$$
\text { Kepemilikan Manajerial }=\frac{\text { Jumlah saham kepemilikan manajerial }}{\text { Jumlah saham biasa yang beredar }}
$$

\section{Struktur Aktiva}

Menurut Riyanto dalam Ernayani, 2015), struktur aktiva adalah penentuan besarnya jumlah alokasi untuk tiap komponen aset, baik dalam bentuk aktiva tetap maupun dalam bentuk aktiva lancar Dimana aktiva lancar merupakan kas dan aktiva lainnya yang dapat disimpan menjadi kas, dijual atau dikonsumsi yang habis dalam waktu tidak lebih dari satu tahun. Sedangkan aktiva tetap adalah aktiva yang dimiliki perusahaan yang bersifat permanen dan dapat habis dalam proses produksi yang memiliki jangka waktu perputaran lebih dari satu tahun. Struktur aktiva dapat diukur dengan rumus sebagai berikut:

$$
\text { Struktur Aktiva }=\frac{\text { Aktiva Tetap }}{\text { Total Aktiva }}
$$

\section{Ukuran Perusahaan}

Ukuran perusahaan merupakan besarnya jumlah aset yang dimiliki oleh sebuah perusahaan yang menggambarkan tinggi rendahnya kegiatan operasional perusahaan. Besar kecilnya ukuran perusahaan akan mempengaruhi struktur modalnya (Nafisa, 2016). Menurut Mardiyati et. al (2014) dan Ernayani (2015) ukuran perusahaan merupakan salah satu hal yang dipertimbangkan perusahaan dalam menentukan kebijakan utangnya karena 
ukuran perusahaan yang besar tentu memiliki sumber daya pendukung yang lebih besar dibandingkan dengan ukuran perusahaan yang lebih kecil. Sesuai dengan pecking order theory yang mengasumsikan bahwa, ukuran perusahaan yang semakin besar dan memiliki tingkat profitabilitas yang tinggi cenderung akan lebih rendah dalam menggunakan utang atau sumber dana eksternal, dikarenakan banyaknya sumber dana internal perusahaan yang dimiliki. Ukuran perusahaan dapat dihitung dengan menggunakan rumus sebagai berikut:

$$
\text { Ukuran Perusahaan }=\text { Ln }(\text { Total Aktiva Perusahaan })
$$

\section{Pertumbuhan Penjualan}

Pertumbuhan penjualan adalah hasil perbandingan antara selisih penjualan tahun berjalan dan penjualan ditahun sebelumnya dengan penjualan ditahun sebelumnya. Brigham dan Houston (2013: 42) berpendapat bahwa perusahaan yang memiliki penjualan yang stabil dapat lebih aman dalam mendapatkan banyak pinjaman dan menanggung biaya tetap yang lebih tinggi dibandingkan dengan perusahaan dengan penjualan yang tidak stabil.Ukuran perusahaan dapat dihitung dengan rumus sebagai berikut:

$$
\text { Pertumbuhan Penjualan }=\frac{\text { Penjualan Tahun } \mathrm{t}-\text { Penjualan Tahun } \mathrm{t}-1}{\text { Penjualan Tahun } \mathrm{t}-1}
$$

\section{Profitabilitas}

Return on asset (ROA) merupakan salah satu proxy dari rasio profitabilitas yang berguna untuk melihat laba dari pendapatan, aset dan modal saham yang dihasilkan oleh perusahaan tersebut (Ratnaningsih, 2016). Tingginya tingkat pengembalian investasi suatu perusahaan, disebabkan karena penggunaan utang yang relatif rendah (Brigham dan Houston, 2013:109). Rendahnya penggunaan utang tersebut dikarenakan perusahaan memiliki sumber dana internal dan laba yang cukup, sehingga mereka tidak mengutamakan penggunaan sumber dana eksternal sebagai bentuk pendanaan kebutuhan kegiatan operasional perusahaan mereka. Mardiyati et. al (2014) menyatakan bahwa semakin tinggi profitabilitas maka akan semakin besar laba yang dapat ditahan untuk operasional perusahaan. ROA dapat dihitung dengan rumus sebagai berikut:

$$
\mathrm{ROA}=\frac{\text { Net Income }}{\text { Total Asset }}
$$




\section{HIPOTESIS}

$\mathrm{H}_{1}$ : Kepemilikan manajerial berpengaruh signifikan terhadap kebijakan utang

$\mathrm{H}_{2}$ : Struktur aktiva berpengaruh signifikan terhadap kebijakan utang

$\mathrm{H}_{3}$ : Ukuran perusahaan berpengaruh signifikan terhadap kebijakan utang

$\mathrm{H}_{4}$ : Pertumbuhan penjualan berpengaruh signifikan terhadap kebijakan utang

$\mathrm{H}_{5}$ : Profitabilitas berpengaruh signifikan terhadap kebijakan utang

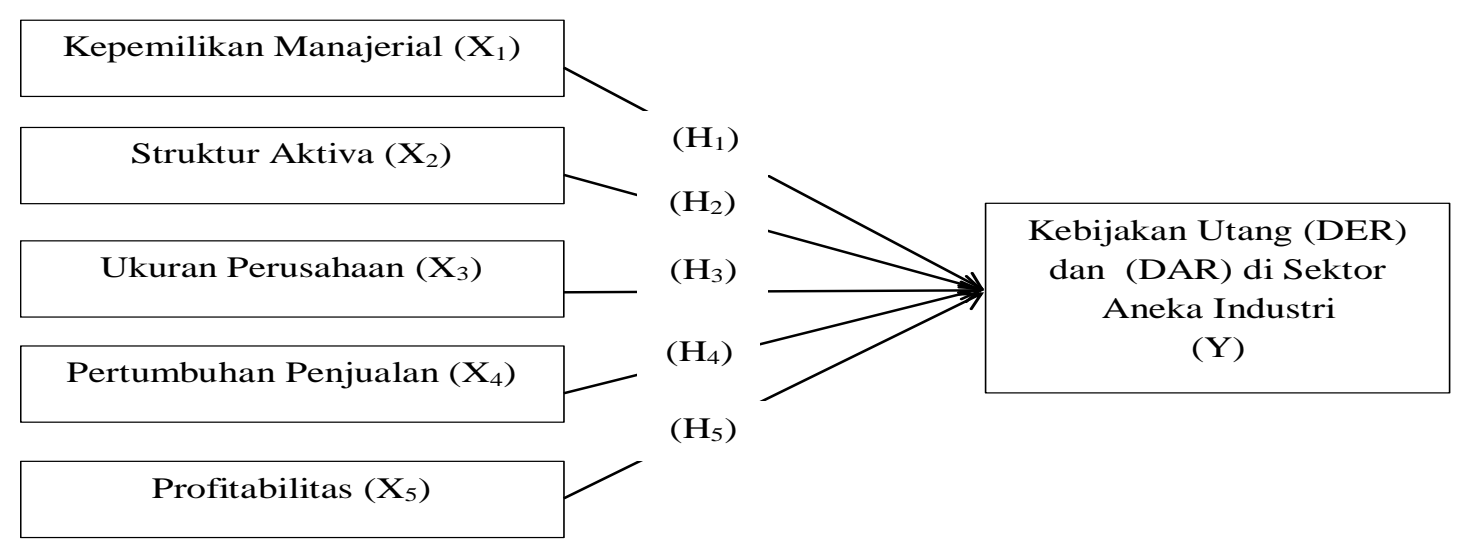

Gambar 1. Model Penelitian

Sumber : Data diolah Penulis (2017)

\section{METODE PENELITIAN}

Populasi dalam penelitian ini adalah perusahaan aneka industri yang terdaftar di Bursa Efek Indonesia (BEI) periode 2012-2016. Penentuan sampel perusahaan dilakukan dengan metode purposive sampling. Berikut kriteria yang harus dimiliki sampel untuk dapat diikutsertakan dalam penelitian ini:

a. Sampel yang digunakan adalah Perusahaan aneka industri yang terdaftar di BEI tahun 2012-2016

b. Perusahaan yang memiliki proporsi saham kepemilikan manajerial dalam laporan tahunan (annual report) minimal 1 tahun

Berdasarkan kriteria tersebut, ditemukan sebanyak 25 perusahaan aneka industri yang memiliki kepemilikan saham manajerial pada perusahaan aneka industri minimal 1 tahun. Adapun jumlah observasi yang digunakan untuk penelitian ini sebanyak 96 perusahaan dengan menggunakan unbalance data. 
Selanjutnya, metode analisis yang digunakan dalam penelitian ini adalah analisis regresi data panel untuk menganalisis pengaruh variabel independen terhadap variabel dependen yang diproksikan oleh Debt to Equity Ratio (DER) dan Debt to Asset Ratio (DAR).

\section{HASIL DAN PEMBAHASAN}

\section{Statistik Deskriptif}

Tabel 1. Statistik Deskriptif

Perusahaan Aneka Industri di Bursa Efek Indonesia

Sumber: Data diolah peneliti menggunakan eviews 9 (2017)

Berdasarkan hasil pada tabel 1 yang menunjukkan statistik deskriptif perusahaan aneka industri sebanyak 96 unit analisis dengan DER dan DAR sebagai proxy dari kebijakan utang, menunjukkan nilai rata- rata kepemilikan saham manajerial (MOWN) sebesar 0,0897 dengan standar deviasi sebesar 0,1678 lebih besar dari nilai rata-rata yang berarti selama periode penelitian perusahaan - perusahaan tersebut memiliki variabilitas MOWN yang tinggi.

Nilai MOWN maksimum perusahaan sektor aneka industri adalah sebesar 0,7000 diperoleh oleh PT. Sat Nusapersada Tbk (PTSN) selama 2012-2016. Sedangkan nilai

\begin{tabular}{llllllll}
\hline & MOWN & SA & $\begin{array}{l}\text { SIZE } \\
\text { (Rp } \\
\text { Miliar) }\end{array}$ & SG & ROA & DER & DAR \\
\hline Mean & 0,0897 & 0,4236 & 3.272 & 0,0494 & 0,0284 & 0,5918 & 0,6998 \\
Median & 0,0186 & 0,4361 & 1.725 & 0,0501 & 0,0221 & 0,8740 & 0,5278 \\
Maximum & 0,7000 & 0,8414 & 18.697 & 0,6122 & 0,4249 & 7,1720 & 4,9982 \\
Minimum & 0,0000 & 0,0954 & 182 & $-0,9989$ & $-0,2907$ & $-30,598$ & 0,0941 \\
Std. & 0,1678 & 0,1956 & 4.076 & 0,2196 & 0,0895 & 3,6721 & 0,8655 \\
Deviation & & & & & & 96 & 96 \\
Observation & 96 & 96 & 96 & 96 & 96 & 96 & 96 \\
\hline
\end{tabular}

minimum MOWN perusahaan sektor aneka industri sebesar 0,000000102 yang diperoleh PT. Apac Citra Centertex Tbk (MYTX). Nilai tersebut menandakan bahwa kepemilikan saham oleh manajerialnya rendah yaitu sebesar 150 lembar saham.

Pada variabel struktur aktiva (SA) menunjukkan nilai rata-rata sebesar 0,4236 dengan nilai standar deviasi sebesar 0,1956. Nilai standar deviasi yang lebih rendah menunjukkan bahwa perusahaan-perusahaan yang menjadi observasi memiliki variabilitas struktur aktiva yang rendah. Jumlah stuktur aktiva tertinggi perusahaan sektor aneka industri adalah sebesar 0,8414 yang diperoleh perusahaan Panasia Indo Resources Tbk. (HDTX) pada tahun 2015. Sedangkan jumlah struktur aktiva terendah perusahaan 
aneka industri adalah sebesar 0,0954 yang diperoleh PT. Grand Kartech Tbk. (KRAH) pada tahun 2016.

Pada variabel ukuran perusahaan (SIZE) menunjukkan rata-rata ukuran perusahaan sebesar Rp 3.272 miliar dengan nilai stadar deviasi sebesar Rp 4.076 miliar. Hal ini mengindikasikan bahwa ukuran perusahaan mempunyai variabilitas yang tinggi selama periode penelitian. SIZE tertinggi perusahaan aneka industri sebesar Rp 18.697 miliar yang dimiliki oleh PT. Gajah Tunggal Tbk. (GJTL) pada tahun 2016 yang mengalami peningkatan dibandingkan tahun sebelumnya yaitu sebesar Rp 17.509 miliar. Sedangkan SIZE terendah terjadi pada perusahaan Astra International Tbk (ASII) pada tahun 2012. Hal ini dikarenakan adanya pelemahan pasar sepeda motor yang secara fundamental pada awal tahun 2012.

Pada variabel sales growth (SG) menunjukkan nilai rata-rata pada perusahaan sektor aneka industri sebesar 0,0494 dengan nilai standar deviasi sebesar 0,2196. Nilai standar deviasi yang lebih besar dari nilai rata-rata mengindikasikan bahwa sales growth mengalami variabilitas yang tinggi selama periode penelitian. Nilai tertinggi dari sales growth (SG) perusahaan aneka industri sebesar 0,6122 yang diperoleh perusahaan PT. Aterliers Mecaniques D'Indonesie Tbk. (AMIN) pada tahun 2015. Hal ini dikarenakan perusahaan berhasil meraih peningkatan pendapatan sebesar $42,20 \%$ pada akhir tahun 2016. Nilai terendah pertumbuhan penjualan perusahaan sektor aneka industri sebesar 0,9989 yang diperoleh perusahaan PT. Nipress Tbk. (NIPS) pada tahun 2016. Nilai pertumbuhan penjualan negatif dikarenakan terjadi penurunan hasil penjualan yang diperoleh.

Pada variabel Return on Asset (ROA) perusahaan aneka industri menunjukkan nilai rata-rata sebesar 0,0284 dan nilai standar deviasi ROA sebesar 0,0895. Besarnya nilai standar deviasi yang melebihi nilai rata-rata mengindikasikan bahwa perusahaan aneka industri periode 2012-2016 memiliki variabilitas ROA yang tinggi. Nilai ROA tertinggi perusahaan sektor aneka industri sebesar 0,4249 yang diperoleh perusahaan PT. Argo Pantes Tbk. (ARGO) pada tahun 2013. Hal tersebut dikarenakan pada 2013, perseroan mencatat adanya kenaikan penjualan sebesar 32\% ditahun 2013. Sedangkan nilai ROA terendah perusahaan aneka industri adalah sebesar -0,2907 yang diperoleh PT. Asia Pacific Fibers Tbk (POLY) pada tahun 2014. Hal ini disebabkan karena pada tahun 2014, 
Indonesia mengalami perlambatan pertumbuhan ekonomi, perlambatan investasi dan belanja pemerintah dan melemahnya permintaan global.

Pada variabel Debt to Equity Ratio (DER) menunjukkan nilai rata-rata perusahaan aneka industri sebesar 0,5918 dengan nilai standar deviasi pada DER sebesar 3,6721 lebih besar dari nilai rata-rata yang berarti memiliki variabilitas DER yang tinggi. Nilai DER tertinggi perusahaan sektor aneka industri adalah sebesar 7,1720 yang diperoleh perusahaan PT. Argo Pantes Tbk. (ARGO) pada tahun 2012. Hal ini dikarenakan di tahun 2012 perseroan mencatat kenaikan liabilitas jangka pendek dari Rp 290.787 miliar di tahun 2011 menjadi Rp 498.085 miliar di tahun 2012. Sedangkan nilai DER terendah perusahaan aneka industri sebesar -30,598 yang diperoleh perusahaan PT. Apac Citra Centertex Tbk (MYTX) pada tahun 2012. Nilai DER negatif ini dikarenakan adanya defisiensi modal yang dialami perusahaan. Hal ini dikarenakan meningkatnya jumlah utang dan menurunnya laba ditahan akibat kerugian yang dialami perusahaan.

Pada variabel Debt to Asset Ratio (DAR) perusahaan aneka industri menunjukkan nilai rata-rata Debt to Asset Ratio (DAR) sebesar 0,6998 dengan nilai standar deviasi sebesar 0,8655. Nilai standar deviasi yang lebih besar menunjukkan bahwa perusahaan yang menjadi observasi memiliki variabilitas DAR yang tinggi. Nilai DAR tertinggi perusahaan sektor aneka industri sebesar 4,9982 yang diperoleh perusahaan PT. Asia Pacific Fibers Tbk (POLY) pada tahun 2016. Sedangkan nilai DAR terendah perusahaan sektor aneka industri sebesar 0,0941 yang diperoleh PT. Tifio Fiber Indonesia Tbk (TFCO) pada tahun 2015. Nilai tersebut menandakan bahwa perusahaan tidak mengutamakan penggunaan utang pada pendanaan operasional perusahaannya.

\section{Uji Multikolinearitas}

Pada tabel 2 tidak ada koefisien korelasi antar variabel yang lebih dari 0,90, yang menandakan bahwa tidak terdapat korelasi antar variabel independen atau terbebas dari multikolinearitas. 
Tabel 2. Hasil Uji Multikolinearitas

\begin{tabular}{llllll}
\hline & MOWN & SA & SIZE & SG & ROA \\
\hline MOWN & 1 & 0.112542 & -0.221775 & -0.129574 & -0.000105 \\
SA & 0.112542 & 1 & 0.310542 & -0.094206 & -0.219208 \\
SIZE & -0.221775 & 0.310542 & 1 & 0.0483471 & -0.095603 \\
SG & -0.129574 & -0.094206 & 0.048347 & 1 & 0.242569 \\
ROA & -0.000105 & -0.219208 & -0.095603 & 0.242569 & 1 \\
\hline
\end{tabular}

Sumber: Data diolah peneliti menggunakan eviews 9 (2017)

\section{Metode Estimasi}

Berdasarkan hasil uji chow pada tabel 3 dan tabel 4 menghasilkan nilai probabilitas sebesar 0,000 lebih kecil dari 0,05. Maka, hasil tersebut menunjukkan bahwa model terbaik untuk penelitian ini adalah dengan menggunakan pendekatan fixed effect model.

Tabel 3. Hasil Uji Chow

Perusahaan Sektor Aneka Industri ( $Y=D E R)$

Redundant Fixed Effects Tests

Equation: FIXED

Test cross-section fixed effects

\begin{tabular}{lrrr}
\hline \hline Effects Test & Statistic & d.f. & Prob. \\
\hline \hline Cross-section F & 22.974171 & $(24,66)$ & 0.0000 \\
Cross-section Chi-square & 214.639695 & 24 & 0.0000 \\
\hline \hline
\end{tabular}

Sumber : Data diolah peneliti menggunakan eviews 9 (2017)

Tabel 4. Hasil Uji Chow

Perusahaan Sektor Aneka Industri ( $Y=D A R)$

Redundant Fixed Effects Tests

Equation: FIXED

Test cross-section fixed effects

\begin{tabular}{lrrr}
\hline \hline Effects Test & Statistic & d.f. & Prob. \\
\hline \hline Cross-section F & 33.712708 & $(24,66)$ & 0.0000 \\
Cross-section Chi-square & 248.130157 & 24 & 0.0000 \\
\hline
\end{tabular}

Sumber : Data diolah peneliti menggunakan eviews 9 (2017)

Selanjutnya dilakukan uji Hausman untuk menentukan model estimasi yang tepat

Tabel 5. Hasil Uji Hausman

Perusahaan Sektor Aneka Industri (Y= DER)

Correlated Random Effects - Hausman Test

Equation: RANDOM

Test cross-section random effects

\begin{tabular}{lccc}
\hline \hline Test Summary & $\begin{array}{l}\text { Chi-Sq. } \\
\text { Statistic }\end{array}$ & Chi-Sq. d.f. & Prob. \\
\hline \hline Cross-section random & 9.980660 & 5 & 0.0758 \\
\hline \hline
\end{tabular}

Sumber : Data diolah peneliti menggunakan eviews 9 (2017) 
Tabel 6. Hasil Uji Hausman

Perusahaan Sektor Aneka Industri (Y= DAR)

Correlated Random Effects - Hausman Test

Equation: RANDOM

Test cross-section random effects

\begin{tabular}{lrrr}
\hline \hline Test Summary & $\begin{array}{l}\text { Chi-Sq. } \\
\text { Statistic }\end{array}$ & Chi-Sq. d.f. & Prob. \\
\hline \hline Cross-section random & 14.961252 & 5 & 0.0105 \\
\hline \hline
\end{tabular}

Sumber : Data diolah peneliti menggunakan eviews 9 (2017)

Berdasarkan hasil uji Hausman pada tabel 5 menghasilkan nilai probabilitas sebesar 0,0758 sehingga model terbaik adalah random effect model. Sedangkan berdasarkan table 6 menghasilkan nilai probabilitas sebesar 0,0105 sehingga fixed effect model merupakan model terbaik.

Tabel. 7 Hasil Rekapitulasi Uji t

\begin{tabular}{cllll} 
& \multicolumn{2}{c}{$\begin{array}{c}\text { A } \\
\text { (Y=DER) }\end{array}$} & \multicolumn{2}{c}{$\begin{array}{c}\text { B } \\
\text { (Y=DAR) }\end{array}$} \\
\hline Variable & Coeff. & Prob. & Coeff. & Prob. \\
\hline MOWN & 2.683329 & 0.3622 & -0.264518 & 0.6833 \\
SA & -2.047254 & 0.3789 & 0.481443 & 0.3330 \\
SIZE & 0.844930 & $\mathbf{0 . 0 6 9 9}$ & -0.211002 & $\mathbf{0 . 0 4 9 4}$ \\
SG & 2.351899 & $\mathbf{0 . 0 0 2 1}$ & -0.088568 & 0.5167 \\
ROA & 12.50763 & $\mathbf{0 . 0 0 0 0}$ & -0.488583 & 0.2355 \\
$\begin{array}{c}\text { Adjusted R- } \\
\text { squared }\end{array}$ & \multicolumn{2}{c}{0.2616} & \multicolumn{2}{c}{0.9215} \\
$\begin{array}{c}\text { Observation } \\
\text { Regression } \\
\text { Model }\end{array}$ & \multicolumn{2}{c}{ Random Effect } & \multicolumn{2}{c}{ Fixed Effect } \\
\hline
\end{tabular}

Sumber: Data diolah peneliti (2017)

\section{Hasil Pengujian Hipotesis}

\section{Pengaruh Kepemilikan Manajerial Terhadap Kebijakan Utang}

Tabel 7 pada kolom A menunjukkan bahwa nilai koefsien kepemilikan manajerial sebesar 2,6833 dan nilai probabilitasnya sebesar 0,3622 lebih besar dari 0,05. Artinya, pengaruh kepemilikan manajerial terhadap kebijkan utang perusahaan aneka industri (DER) tidak signifikan. Hal ini menandakan bahwa besar atau kecilnya kepemilikan saham oleh pihak manajerial tidak berpengaruh terhadap keputusan pendanaan dan kebijakan utang perusahaan. Hasil ini sejalan dengan penelitian yang dilakukan oleh Susanti (2013), Murtiningtyas (2012), Indahningrum dan Handayani (2009) yang menyatakan bahwa kepemilikan manajerial tidak berpengaruh terhadap kebijakan utang. 
Hal ini disebabkan rendahnya kepemilikan saham manajerial dibandingkan dengan kepemilikan oleh kelompok lainnya, sehingga manajer tidak dapat menggunakan wewenangnya untuk menentukan sumber pendanaan.

Selanjutnya peneliti melakukan robustness check pada variabel kepemilikan manajerial dengan DER dan DAR sebagai proxy dari kebijakan utang. Terlihat pada kolom B bahwa kepemilikan manajerial tidak berpengaruh signifikan terhadap kebijakan utang perusahaan. Dengan demikian dapat disimpulkan dari kedua hasil regresi pada tabel 7 bahwa pengaruh kepemilikan manajerial terhadap kebijakan utang memiliki hasil robust, yaitu keduanya tidak signifkan.

\section{Pengaruh Struktur Aktiva Terhadap Kebijakan Utang}

Tabel 7 pada kolom A menunjukkan nilai koefisien struktur aktiva sebesar -2,0472 dan nilai probabilitasnya sebesar 0,3789 lebih besar dari 0,05. Artinya, struktur aktiva tidak berpengaruh terhadap kebijakan utang perusahaan aneka industri (DER). Hasil ini sesuai dengan penelitian Susanti (2013), Hani dan Rahmi (2014), Cekrezi (2013) dan Puspitasari dan Manik (2016) yang menyatakan bahwa struktur aktiva tidak berpengaruh terhadap kebijakan utang (DER). Hal ini dikarenakan rendahnya persentase struktur aktiva yang dimiliki perusahaan sehingga aktiva tetap yang dimiliki perusahaan tidak cukup sebagai jaminan untuk melaksanakan kebijakan utang.

Selanjutnya peneliti melakukan robustness check pada struktur aktiva perusahaan aneka industri dengan DER dan DAR sebagai proxy dari kebijakan utang. Terlihat pada kolom B nilai koefisien struktur aktiva sebesar 0,4814 dengan nilai probabilitas sebesar 0,3330 lebih besar dari 0,05. Artinya, struktur aktiva tidak berpengaruh terhadap kebijakan utang perusahaan aneka industri (DAR). Hasil ini sesuai dengan penelitian Prathiwi dan Yadnya (2017) dan Junaidi (2013) yang menyatakan bahwa struktur aktiva tidak berpengaruh terhadap kebijakan utang (DAR). Hal tersebut dikarenakan akan meningkatkan biaya modal apabila perusahaan menggunakan utang sebagai sumber dana utama. Dengan demikian dapat disimpulkan dari kedua hasil regresi pada tabel 7 bahwa pengaruh ukuran struktur aktiva terhadap kebijakan utang memiliki hasil robust, yaitu keduanya tidak signifikan. 


\section{Pengaruh Ukuran Perusahaan Terhadap Kebijakan Utang}

Tabel 7 pada kolom A menunjukkan nilai koefisien ukuran perusahaan sebesar 0,8449 dengan nilai probabilitas sebesar 0,0699. Artinya, ukuran perusahaan berpengaruh positif signifikan terhadap kebijakan utang (DER) dengan taraf signifikansi sebesar $10 \%$. Hasil penelitian ini sesuai dengan hasil penelitian Joher et. al (2006), Sudiyatno dan Mustika (2013), Mahnazmahdavi et. al (2013) dan Nafisa (2016) yang menyatakan bahwa ukuran perusahaan memiliki pengaruh positif signifikan terhadap kebijakan utang. Hal tersebut disebabkan karena semakin besar ukuran perusahaan, maka semakin besar pula penggunaan utang perusahaan. Perusahaan dengan ukuran yang lebih besar, lebih mudah mendapatkan sumber pendanaan dan pinjaman kreditur karena mempunyai jaminan yang juga besar.

Selanjutnya peneliti melakukan robustness check pada perusahaan aneka industri dengan DER dan DAR sebagai proxy dari kebijakan utang. Pada kolom B menunjukkan nilai koefisien ukuran perusahaan sebesar -0,2110 dengan nilai probabilitas sebesar 0,0494. Hal ini berarti ukuran perusahaan berpengaruh negatif signifikan terhadap kebijakan utang perusahaan (DAR). Hasil penelitian Ting dan Lean (2011) dan Hayat et. al (2016) juga menyatakan bahwa ukuran perusahaan berpengaruh negatif signifikan terhadap kebijakan utang. Artinya, perusahaan yang relatif besar mungkin biasa mendapatkan keuntungan lebih dari banyak perusahaan kecil. Oleh karena itu, perusahaan yang lebih besar lebih suka menggunakan dana internal, bukan dana eksternal berupa utang yang mahal. Dengan demikian dapat ditemukan dari kedua hasil regresi pada tabel 7 bahwa pengaruh ukuran perusahaan terhadap kebijakan utang memiliki hasil robust, dimana keduanya berpengaruh signifikan.

\section{Pengaruh Pertumbuhan Penjualan Terhadap Kebijakan Utang}

Tabel 7 kolom A menunjukkan nilai koefisien pertumbuhan penjualan sebesar 2,3518 dengan nilai probabilitas sebesar 0,0021. Artinya, pertumbuhan penjualan memiliki pengaruh positif terhadap kebijakan utang (DER). Hasil penelitian Hidayat (2013), Mahnazmahdavi et. al (2013) dan Geovana (2015) juga menyatakan bahwa pertumbuhan penjualan berpengaruh positif signifikan terhadap kebijakan utang. Hal ini dikarenakan perusahaan yang memiliki tingkat pertumbuhan yang tinggi cenderung membutuhkan dana dari sumber dana eksternal yang lebih besar. Selain itu, para investor 
juga akan menilai dan yakin kepada perusahaan jika perusahaan tersebut dapat mengelola utangnya dengan baik dan mampu menangani risiko atas utang tersebut, sehingga perusahaan akan menambah tingkat utangnya.

Selanjutnya, peneliti melakukan robustness check pada perusahaan aneka industri dengan DER dan DAR sebagai proxy dari kebijakan utang. Terlihat pada kolom B, nilai koefisien pertumbuhan penjualan sebesar -0,0885 dengan nilai probabilitas sebesar 0,5167. Artinya, pertumbuhan penjualan tidak bepengaruh terhadap kebijkan utang (DAR). Hasil pada kolom B ini sesuai dengan hasil penelitian Damayanti dan Hartini (2013), Hani dan Rahmi (2014), Rufina (2014) dan Resino et. al (2015) yang menyatakan bahwa pertumbuhan penjualan perusahaan tidak berpengaruh signifikan terhadap kebijakan utang. Hal ini dikarenakan nilai pertumbuhan penjualan dari tahun ke tahun berfluktuasi sehingga pihak manajemen perusahaan merasa bahwa kondisi tersebut merupakan pertanda yang kurang baik bagi perusahaan. Dengan demikian dapat disimpulkan dari kedua hasil regresi pada tabel 7 bahwa pengaruh pertumbuhan penjualan terhadap kebijakan utang memiliki hasil tidak robust.

\section{Pengaruh Profitabilitas (ROA) Terhadap Kebijakan Utang}

Tabel 7 pada kolom A menunjukkan nilai koefisien profitabilitas sebesar 12,5076 dengan nilai probabilitas sebesar 0,0000. Artinya, profitabilitas (ROA) berpengaruh positif signifikan terhadap kebijakan utang. Perusahaan lebih memilih menggunakan utang untuk ekspansi dan laba yang tinggi tersebut tetap digunakan untuk pendanaan internal perusahaan. Hasil ini mendukung hasil penelitian Abor (2007) dan Susanti (2013) yang menunjukkan profitabilitas berpengaruh positif signifikan terhadap kebijakan utang. Hal tersebut disebabkan perusahaan yang memiliki prospek yang menguntungkan akan lebih menghindari penjualan saham dan lebih memilih utang sebagai modal baru.

Selanjutnya peneliti melakukan robustness check pada profitabilitas perusahaan aneka industri dengan DER dan DAR sebagai proxy dari kebijakan utang. Terlihat pada tabel 7 kolom B, nilai koefisien sebesar -0,4885 dengan nilai probabilitas sebesar 0,2355. Artinya, profitabilitas tidak memiliki pengaruh signifikan terhadap kebijakan utang. Hasil ini sesuai dengan hasil penelitian Puspitasari dan Manik (2016) dan Ratnaningsih (2016) yang menyatakan bahwa profitabilitas suatu perusahaan tidak berpengaruh terhadap 
kebijakan utang. Dengan demikian, dari kedua hasil regresi pada tabel 7 bahwa pengaruh profitabilitas terhadap kebijakan utang memiliki hasil tidak robust.

\section{Koefisien Determinasi}

Berdasarkan hasil regresi yang ditampilkan pada tabel 7 kolom A, menunjukkan nilai adjusted $R$-square sebesar 0,26. Nilai tersebut mencerminkan bahwa perusahaan dengan DER sebagai proxy kebijakan utang, Debt to Equity Ratio (DER) dapat dijelaskan oleh kelima variabel idependennya, yaitu kepemilikan manajerial, struktur aktiva, ukuran perusahaan, pertumbuhan penjualan dan profitabilitas sebesar $26 \%$. Sedangkan sisanya sebesar 74\% dijelaskan faktor-faktor lain diluar variabel independen pada penelitian ini. Selanjutnya, hasil regresi model perusahaan aneka industri dengan DAR sebagai proxy dari kebijakan utang, nilai adjusted $R$-square sebesar 0,92. Nilai tersebut mencerminkan Debt to Asset Ratio (DAR) dapat dijelaskan oleh kelima variabel independennya sebesar 92\%. Sedangkan sisanya sebesar $8 \%$ dijelaskan faktor-faktor lain diluar variabel independen pada penelitian ini. Dari kedua nilai adjusted $R$-square tersebut dapat disimpulkan bahwa kepemilikan manajerial, struktur aktiva, ukuran perusahaan, pertumbuhan penjualan dan profitabilitas mempunyai pengaruh yang besar terhadap DER dibandingkan dengan pengaruhnya terhadap DAR.

\section{KESIMPULAN DAN SARAN}

\section{Kesimpulan}

1. Kepemilikan manajerial dan struktur aktiva tidak berpengaruh terhadap kebijakan utang dengan menggunakan DER dan DAR sebagai proxy kebijakan utang dan memberikan hasil robust.

2. Ukuran perusahaan berpengaruh positif signifikan terhadap kebijakan utang dengan menggunakan proxy DER dan berpengaruh negatif signifikan terhadap DAR sebagai proxy kebijakan utang dan memberikan hasil robust.

3. Pertumbuhan penjualan dan profitabilitas berpengaruh positif signifikan terhadap kebijakan utang dengan DER sebagai proxy dari kebijakan utang, sedangkan dengan DAR tidak berpengaruh signifikan dan memberikan hasil tidak robust. 


\section{Implikasi}

Penelitian ini diharapkan dapat membantu manajemen perusahaan dalam membuat keputusan tentang kebijakan pendanaannya, yaitu memperhatikan size, sales growth, dan ROA. Perusahaan yang menghasilkan laba akan lebih cenderung menggunakan dana dari laba ditahan dan modal saham untuk membiayai kegiatan operasionalnya daripada pendanaan eksternal melalui utang seperti pada pecking order theory karena risiko yang akan dihadapi oleh perusahaan lebih kecil.

\section{Saran}

1. Melakukan penelitian pada sektor perusahaan yang beragam untuk mengetahui perbandingan dengan hasil penelitian sebelumnya.

2. Menambahkan variasi proxy seperti Long Term Debt Ratio (LTDR) pada variabel dependen agar dapat diketahui perbedaan dari masing-masing proxy yang digunakan.

3. Menggunakan variabel independen yang berpengaruh di dalam penelitian ini untuk meningkatkan nilai koefisien determinasi $\left(R^{2}\right)$.

4. Menambahkan jumlah observasi agar hasil yang didapat lebih akurat

\section{DAFTAR PUSTAKA}

Abor, J. 2007. Debt policy and performance of SMEs: evidence from Ghanaian and South Africa firms. Journal of Risk Finance, 8(1), 364-79.

Brigham, F. E., and Houston, F. J. 2013. Dasar - dasar Manajemen Keuangan (11 ed.).(Terjemahan Ali Akbar Yulianto).Jakarta: Salemba Empat.

Bursa Efek Indonesia. Laporan Keuangan dan Tahunan. http://www.idx.co.id/id$\mathrm{id} /$ beranda/perusahaantercatat/laporankeuangandantahunan.aspx. (Diakses pada 4 Februari 2017).

Çekrezi, A. 2013. Impact of Firm Specific Factors on Capital Structure Decision: An Empirical Study of Albanian Firms. European Journal of Sustainable Development, 2(4), 135-148.

Damayanti, D., dan Titin Hartini, S. M. 2013. Pengaruh Profitabilitas, Likuiditas, Pertumbuhan Penjualan dan Ukuran Perusahaan Terhadap Kebijakan Utang Pada Perusahaan Sektor Consumer Goods di BEI Periode 2008-2012. Jurnal Manajemen dan Bisnis, 1-10.

Fama, E., F. 1980. Agency Problems and The Theory of The Firm. Journal of political, $88(2)$. 
Ernayani, R., Anam, H., dan Dwi, C. 2015. Pengaruh Struktur Aset, Ukuran Perusahaan dan Pertumbuhan Perusahaan Terhadap Kebijakan Utang (Studi pada Perusahaan Farmasi periode 2010-2014). Journal of Sustainable Competitive Advantage, 114.

Geovana, Rosella. S., dan Andayani. 2015. Pengaruh Growth Sales, Profitabilitas, Operating Leverage dan Tax Rate Terhadap Kebijakan Utang. E-Jurnal Ilmu dan Riset Akuntasi, 4(4).

Hani, S., dan Rahmi, D. A. 2014. Analisis Pertumbuhan Penjualan dan Struktur Aktiva Terhadap Struktur Pendanaan Eksternal. Jurnal Manajemen \& Bisnis, 14(01), 8997.

Hayat, M., Wang M., and Ma J. 2016. The Impact of Ownership Structure on Corporate Debt Financing: Evidence from the Manufacturing Sector of Pakistan. International Journal of Management Theory and Practices, $\quad$ 17(1), 92-109.

Hidayat, M. S. 2013. Pengaruh Kepemilikan Manajerial, Kebijakan Dividen, Struktur Aktiva, Pertumbuhan Penjualan, dan Ukuran Perusahaan Terhadap Kebijakan Utang. Jurnal Ilmu Manajemen, 1(1), 12-25.

Indahningrum, R., dan Handayani, R. 2009. Pengaruh Kepemilikan Managerial, Kepemilikan Institusional, Dividen, Pertumbuhan Perusahaan, Free Cash Flow dan Profitabilitas terhadap Kebijakan Utang Perusahaan. Jurnal Bisnis dan Akuntansi, 11(3), 189-207.

Joher, H., Ali, M., dan Nazrul. 2006. The Impact Of Ownership Structure On Corporate Debt Policy: Two Stage Least Square Simultaneous Model Approach For Post Crisis Period: Evidence From Kuala Lumpur Stock Exchange. International Business \& Economics Research Journal, 5(5), 5164.

Junaidi, A., A. 2013. Analisis Pengaruh Free Cash Flow, Struktur Kepemilikan, Kebijakan Dividen, Struktur Aktiva, dan Profitabilitas Terhadap Kebijakan Hutang Perusahaan. Jurnal Riset Akuntansi, 1(1).

Kementerian Perencanaan Pembangunan Nasional. Menteri Paparkan 10 Prioritas Nasional dan 30 Program Prioritas. 2017. http://www.bappenas.go.id/id/beritadan-siaran-pers/musrenbangnas-2017 untuk-penyusunan-rkp-2018-menteribambang-paparkan-10-prioritas-nasional -dan-30-program-prioritas. (Diakses pada tanggal 29 April 2017).

Mahnazmahdavi, Mokhtarbaseri, Zare, A., and Zare, H. 2013. The effect of sales growth on the determinants of capital structure of listed companies in Tehran Stock Exchange. Australian Journal of Basic and Applied Sciences, 7(2), 306-311 
Mardiyati, U., Susanti, S., and Ahmad, G. N. 2014. Pengaruh Kepemilikan Institusional, Ukuran Perusahaan, Profitabilitas dan Risiko Bisnis Terhadap Kebijakan Utang Pada Perusahaan Manufaktur Yang Terdaftar di Bursa Efek Indonesia Periode 2008-2012. Jurnal Riset Manajemen Sains Indonesia (JRMSI), 5(1), 84-99.

Margaretha, F. 2014. Determinants of Debt Policy in Indonesia's Public Company. Journal of Business and Economic, 3(2), 10-16.

Murtiningtyas, A. I. 2012. Kebijakan Dividen, Kepemilikan Manajerial, Kepemilikan Institusional, Profitabilitas, Resiko Bisnis Terhadap Kebijakan Utang. Accounting Analysis Journal, 1(2), 1-6.

Nafisa, A., Dzajuli, A., and Djumahir. 2016. Pengaruh Kepemilikan Manajerial, Kepemilikan Institusional, Ukuran Perusahaan, Pertumbuhan Perusahaan, Free Cash Flow dan Profitabilitas terrhadap Kebijakan Utang Perusahaan Manufaktur di Bursa Efek Indonesia. Jurnal Ekonomi Bisnis, 122-135.

Narita, Rona Mersi. 2012. Analisis Kebijakan Utang. Accounting Analysis Journal, 1(2).

Prathiwi, N. M. dan Yadnya, I. P. 2017. Pengaruh Free Cash Flow, Struktur Aset, Risiko Bisnis Dan Profitabilitas Terhadap Kebijakan Hutang. E-Jurnal Manajemen Unud, 6(1), 60-86.

Puspitasari S., dan Manik, T. 2016. Pengaruh Struktur Aset, Current Ratio, Return On Assets, Net Profit Margin, Pertumbuhan Perusahaan Terhadap Kebijakan Utang (Studi Pada Perusahaan Manufaktur yang Go Public di Bursa Efek Indonesia Pada Periode Tahun 2011-2014). Jurnal Akuntansi, 1-25.

Ratnaningsih, U. 2016. Pengaruh Kepemilikan Manajerial, Kepemilikan Institusional, Kebijakan Dividen, Struktur Aset dan Return On Asset (ROA) Terhadap Kebijakan Utang pada Perusahaan Manufaktur yang Terdaftar di Bursa Efek Indonesia Tahun 2010-2014. Jurnal Akuntansi, 1-23.

Rufina, D. 2014. Analisis Faktor-Faktor Yang Mempengaruhi Capital Structure (Pada Perusahaan Yang Termasuk Dalam Index LQ45 Periode 2011-2013. Journal of Economics and Business.1-8

Resino, M., Syafitri, Y., dan Wijaya, T. 2015. Pengaruh Likuiditas, Profitabilirtas, Ukuran Perusahaan dan Pertumbuhan Penjualan Terhadap Struktur Modal. Jurnal ekonomi, 2(4), 1-14.

Saham Ok. Sektor Aneka Industri (4). 2017. https://sahamok.com/emiten/sektor-anekaindustri/. (Diakses pada tanggal 5 Januari 2017).

Soesetio. 2008. Kepemilikan Manajerial dan Institusional, Kebijakan Dividen, Ukuran Perusahaan, Struktur Aktiva dan Profitabilitas Terhadap Kebijakan Utang. Jurnal Keuangan dan Perbankan, 12(3), 384-398. 
Sudiyatno, B., dan Mustika, S. 2013. Determinants of Debt Policy: An Empirical Studying Indonesia Stock Exchange. International Research Journals, 4(1), 98-108.

Sugiyono. 2014. Metode Penelitian Kuantitatif, Kualitatif dan Kombinasi (Mixed Methods) (5 ed.). Bandung: Alfabeta.

Susanti. 2013. Analisis Variabel - Variabel yang Memengaruhi Kebijakan Utang Perusahaan. Jurnal Ilmu Manajemen, 1(3), 798-814.

Ting I. W. and Lean H. H. 2011. Capital Structure Of Government-Linked Companies In Malaysia. Asian Academy of Management Journal of Accounting and Finance,7(2),137-156. 